\title{
EVOLUTION OF SCHISTOSOMIASIS IN AN HYPERENDEMIC AREA OF THE MINAS GERAIS STATE: TWO CROSS-SECTIONAL STUDIES ["]
}

\author{
Maria Fernanda Furtado de Lima e COSTA, R. S. ROCHA, Fábio ZICKER and Naftale KATZ
}

\section{S U M M A R Y}

Two cross-sectional studies on schistosomiasis mansoni were done in Comercinho, Minas Gerais (Brazil), at an interval of 7 years. In 1974 and 1981 feces examinations (KATO-KATZ method) were done in 89 and $90 \%$ of the population (about 1,500 inhabitants) and clinical examinations were done in 78 and $92 \%$ of the patients who excreted Schistosoma mansoni eggs in the feces, respectively. The rate of infection by $\mathbf{S}$. mansoni did not change $69.9 \%$ in 1974 and $70.4 \%$ in $1981)$, but the geometrical mean of eggs per gram of feces $(431 \pm 4$ and $334 \pm 4$, respectively) and the rate of splenomegaly (11 and $7 \%$, respectively) decreased significantly in 1981, when compared to 1974 . This reduction was observed only in the central zones of the town (zones 1-2) where the rate of dwellings with piped water increased from 17 to $44 \%$. In the surroundings (zones $3-4$ ), where the proportion of houses with piped water did not change significantly between 1974 $(10 \%)$ and $1981(7 \%)$, the geometrical mean of S. mansoni eggs and the rate of splenomegaly did not change either.

\section{N T RODUCTION}

A cross-sectional study on schistosomiasis mansoni was done in Comercinho, Minas Gerais State, Brazil. In this study the most interesting finding was the severity of the schistosomiasis (higher infection rate, higher egg count in the feces and higher rate of splenomegaly) in the environments (zones 3-4) compared to the one observed in the central areas in the town (zones 1-2). In zones 3 and 4 the heads of family were predominantly manual workers ( 73 and $94 \%$, respectively), only 3 and $10 \%$ of the houses had piped water and less than $14 \%$ of the dwellings 'were of good quality, while in zones 1 and 2, the economical situation of the heads of family, the quality of the houses, and the water supply 'were better 4 .
In the present paper the results of the cross-sectional study done in 1981 will be compared to one done previously in Comercinho 7 years before. This comparison aims to: a) evaluate if the rate of infection, the counting of S. mansoni eggs in the feces and the rate of splenomegaly in zones 1-2 and 3-4 underwent modifications during the period of survey; $b$ ) if any change had occurred, identify the possible factors responsible for the modification.

\section{MATERIALS AND METHODS}

Comercinho is a town in the northeast of the State of Minas Gerais (Brazil) situated at 701 kilometers from the capital (Belo Horizonte). The town is surrounded by three small

(*) Work supported by the Conselho Nacional de Desenvolvimento Cientffico $\theta$ Tecnológico (CNPq) and by the Financiadora de Estudos e Projetos (FINEP), Brazil

Departamento de Medicina Preventiva e Social, Universidade Federal de Minas Gerais and Centro de Pesquisas "René Rachou", Fundação Oswaldo Cruz. 30,000 - Belo Horizonte, Minas Gerais, Brazil 
COSTA, M. F. F. de L. e; ROCHA, R. S.; ZICIKER, F. \& KATZ, N. - Evolution of schistosomiasis in an hyperendemic area of the Minas Gerais State: two cross-sectional studies. Rev. Inst. Med. trop. São Paulo 27:279-285, 1985.

streams that are used by the population chiefly for domestic activities $(75 \%$ of the contact of the inhabitants of Comercinho with natural waters are for washing clothes and dishes, for bcdy hygiene, and to obtain water from the streams for housekeeping 5). There is no sewage drainage in the town and the intermediate host is Biomphalaria glabrata ${ }^{4}$.

Comercinho was divided into four geographical zones: two situated in the environs (zo nes 3 and 4) and two in the central area of the town (zones 1 and 2). Further details are in COSTA et al. ${ }^{4}$.

The people from Comercinho were examined in 1974 and in 1981: in both periods feces and clinical examination in patients who excreted S. mansoni eggs were done. No schistosomiasis control program was made in the area during the period of study.

A complete census in the town was done in May, 1974 and in May, 1981; forms were filled out with name, date of birth and sex of the inhabitants as well as the origin of the water supply in the house (whether with or without piped public water).

The feces examinations were done by the KATO-KATZ method ${ }^{10}$. Two slides from each sample of feces were prepared and the mean of the two egg counts was considered as the number of S. mansoni eggs per gram of feces of the patient.

The clinical examinations were done by one physician in 1974 and by another from the same staff in 1981. The individuals were examined in decubitus dorsales and in right lateral decubitus being considered palpable the liver and spleen detected immediatly below the costal margin, breath held. The PESSOA \& BARROS 12 clinical classification was used with slight modifications: Type I - liver and spleen not palpable, or palpable liver with normal consistency; Type II - hardened palpable liver; Type III - palpable spleen or splenectomized patients.

\section{Statistic analysis}

To evaluate the statistic significance of the differences between the means, STUDENT's $t$ test was used, and for the differences between the frequencies, the $\mathrm{X}^{2}$ test with YATES correc tion was used. The results from 1974 and 1981 were adjusted by the age, according to the weighted standard population (the statistic analysis of the differences between the adjusted rates were done through the method of the minimum variance). The minimum level of significance considered was $95 \% 13$.

\section{RESULTS}

The Fig. 1 shows the distribution of the population from Comercinho, according to sex and age, as well as the rate of patients that underwent clinical and/or feces examinations ir: 1974 and 1981. In 1974 and in 1981 there were respectively 1487 and 1474 persons living in the town; the feces examination was done in 88.8 and $90.2 \%$ of the whole population and the clinical examination was done in 78.2 and $92.2 \%$ of the positive patients, respectively.

The rate of infection by $\mathbf{S}$. mansoni did not change during the analysed period (69.9 and $70.4 \%$ ), but the geometric mean of eggs in the feces and the rate of splenomegaly decreased significantly in 1981, when compared to 1974 (Table I). These similarities and differences remained when the results of both periods were adjusted by the age of the standard population (rate of infection $=70.3$ and $70.2 \%$; rate of patients with $\supseteq 1000$ eggs per gram of feces $=$ 31.7 and $24.0 \%$, and rate of splenomegaly $=$ 11.4 and $6.6 \%$ in 1974 and 1981 , respectively).

Table II shows the rate of infection, the egg counting and the distribution of the clinical forms in zone 1-2 and 3-4. In regard to zones 1.2, the following results are remarkable: a) the rate of infection in children and adults did not change between 1974 and 1981; b) the geometric mean of eggs in children and in adults (treated or not) decreased significantly between 1974 and 1981; c) the proportion of children with splenomegaly decreased from $10.6 \%$ in 1974 to $2.5 \%$ in 1981 ; d) the rate of splenomegaly in adults was statistically similar in both periods (9.2\% in 1974 and $5.1 \%$ in 1981). In zones $3 * 4$, the only statistically significant difference between 1974 and 1981 was the increase of the rate of infection in children (from 68.0 to $80.8 \%$ ).

Table III shows the water supply, electricity in the house, the pavement of streets, the po- 
FIg. I - DISTRIBUTION OF THE INHABITANTS OF COMERCINHO (1974/1981), ACCORDING TO THE AGE, SEX, THE RESULT OF THE FECES EXAMINATION, AND THE CONDITION OF HAVING UNDERGONE THE CLINICAL EXAMINATION.
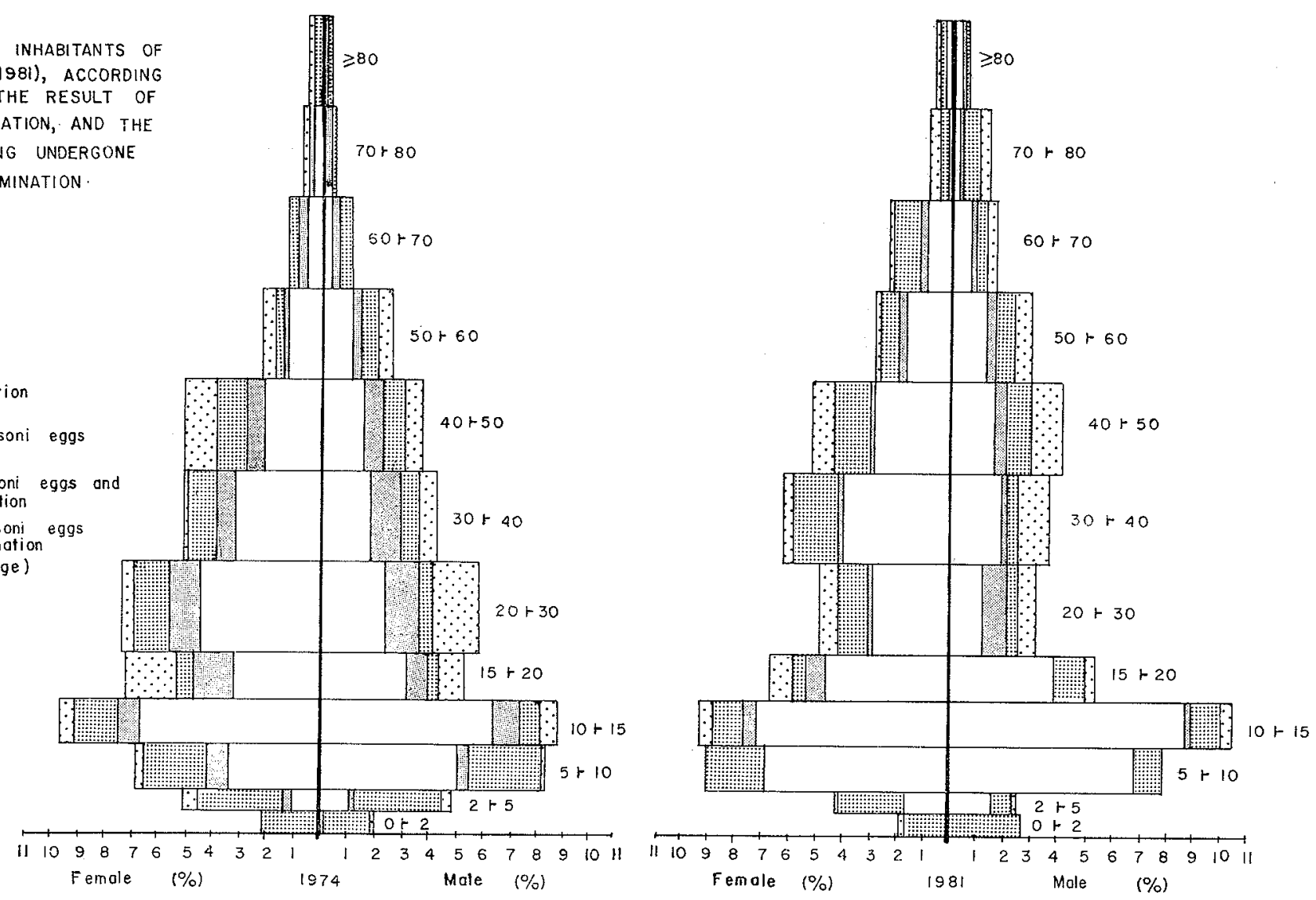

$\because$ Without reces examinotion

Without Schistosomo mansoni eggs in the feces

7 With schistosomo mansoni without clinical exansoni

with schistosoma

With Schistosomu mansoni egg Xfr: Age group (years of age)

Female $(\%)$

198

Male 
COSTA, M. F. F. de L. e; ROCHA, R. S.; ZICKER, F. \& KATZ, N. - Evolution of schistosomiasis in an hyperendemic area of the Minas Gerais State: two cross-sectional studies. Rev. Inst. Med. trop. São Paulo 27:279-285, 1985.

T A B L E I

Rate of infection, Schistosoma mansoni EGG count and schistosomiasis clinical forms (Comercinho, 1974/1981)

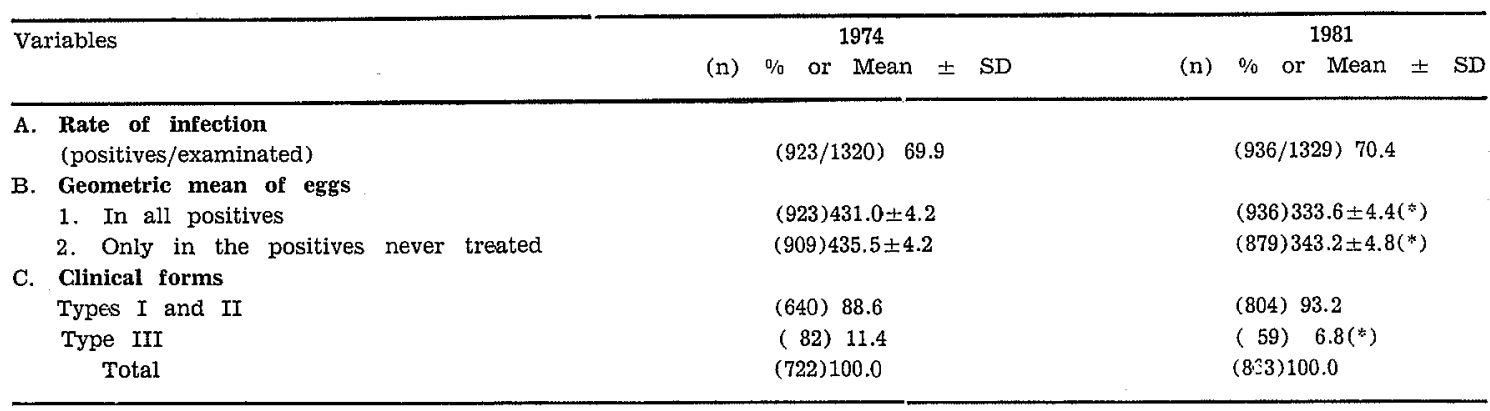

(*) Statistically significant differences between 1974 and 1981 ( $\mathrm{X}^{2}$ or STUDENT's $\mathrm{t}$ test) $-\mathrm{p}<0.05$

T A B L E II

Rate of infection, Schistosoma mansoni EGG count and schistosomiasis clinical forms in children and adults, according to the geographical zone (Comercinho, 1974/1981)

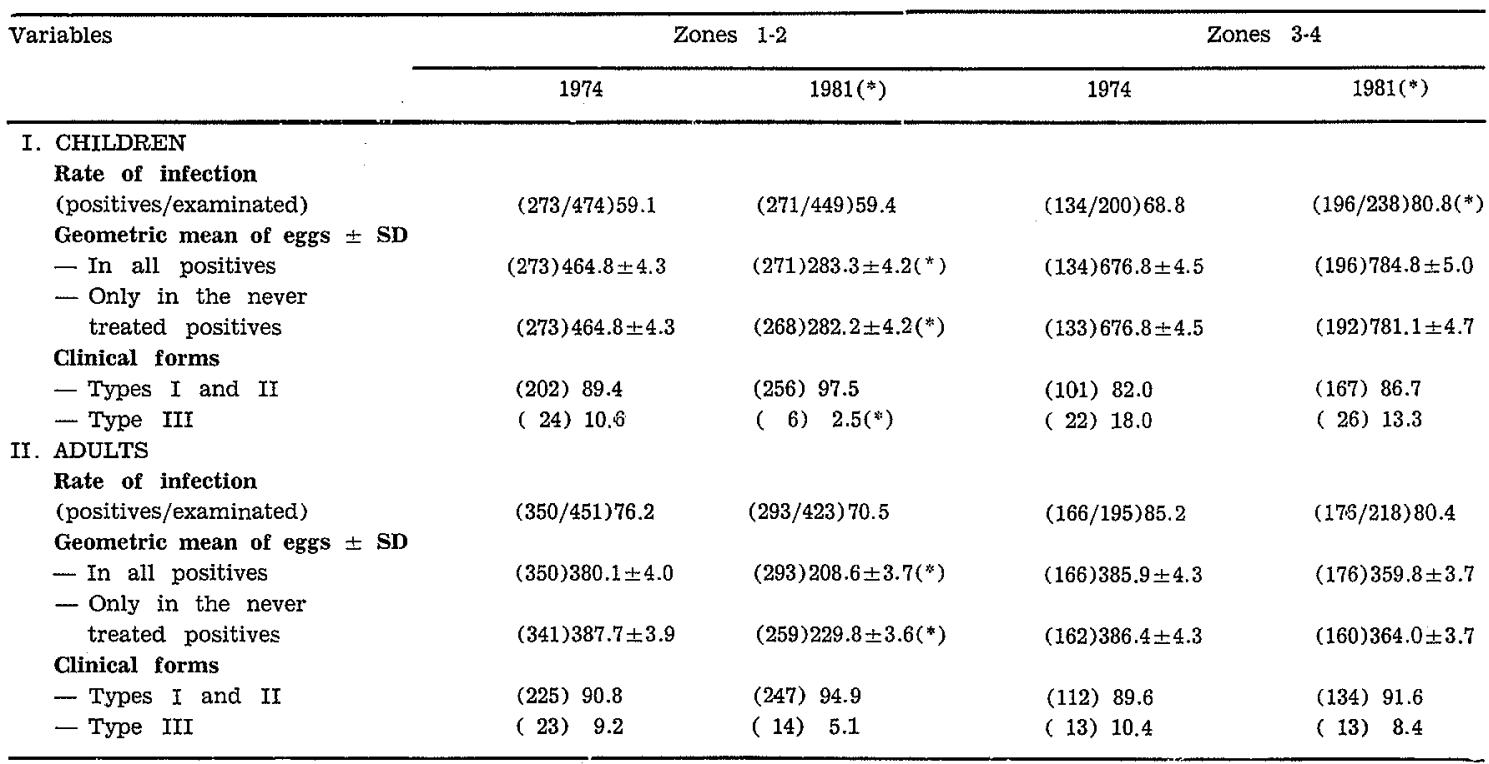

(n) $\%$ or Mean \pm SD

$\%$ : Age standardized rates (Direct method)

(*) Statistically significant differences between 1974 and 1981 (method of the minimum variance or STUDENT's $t$ test) Children: $0-14$ and Adults: $\supseteq 15$ years of age

pulation examined and the report of specific treatment according to the geographical zone. The following differences were observed between 1974 and 1981: a) the proportion of houses with piped water increased from 16.6 to $44.4 \%$ in zones $1-2 ; \mathrm{b}$ ) the proportion of houses with electricity increased significantly in zones $1-2$ and in zones $3-4 ; c)$ two streets in zones 1-2 were paved in 1974 and in 198111 paved streets were found; d) in 1974 less children were clinically examined in zones $1-2$ and $3-4$, and less adults in zones 1-2 than in 1981. The proportion of patients who underwent feces examinations and the proportion of treated children were statistically similar in 1974 and 1981 in zones 1-2 as well as in zones 3-4.

\section{DISCUSSION}

Periodic cross-sectional studies in endemic areas permit an evaluation of whether schistosomiasis is increasing or decreasing. BARBOSA $\&$ VOSS ${ }^{1}$ made two cross-sectional studies on schistosomiasis in Água Preta (northeast of Brazil) and found that the rate of infection by S. mansoni had not been changed 7 years after 
COSTA, M. F. F. de L. e; ROCHA, R. S.; ZICKER, F. \& KATZ, N. - Evolution of schistosomiasis in an hyperendemic area of the Minas Gerais State: two cross-sectional studies. Rev. Inst. Med. trop. São Paulo 27:279-285, 1985.

T A B L E III

Water supply and electricity in the houses, paved streets, examined population and report of treatment with schistoso. micides, according to the geographical zones (Comercinho, 1974/1981)

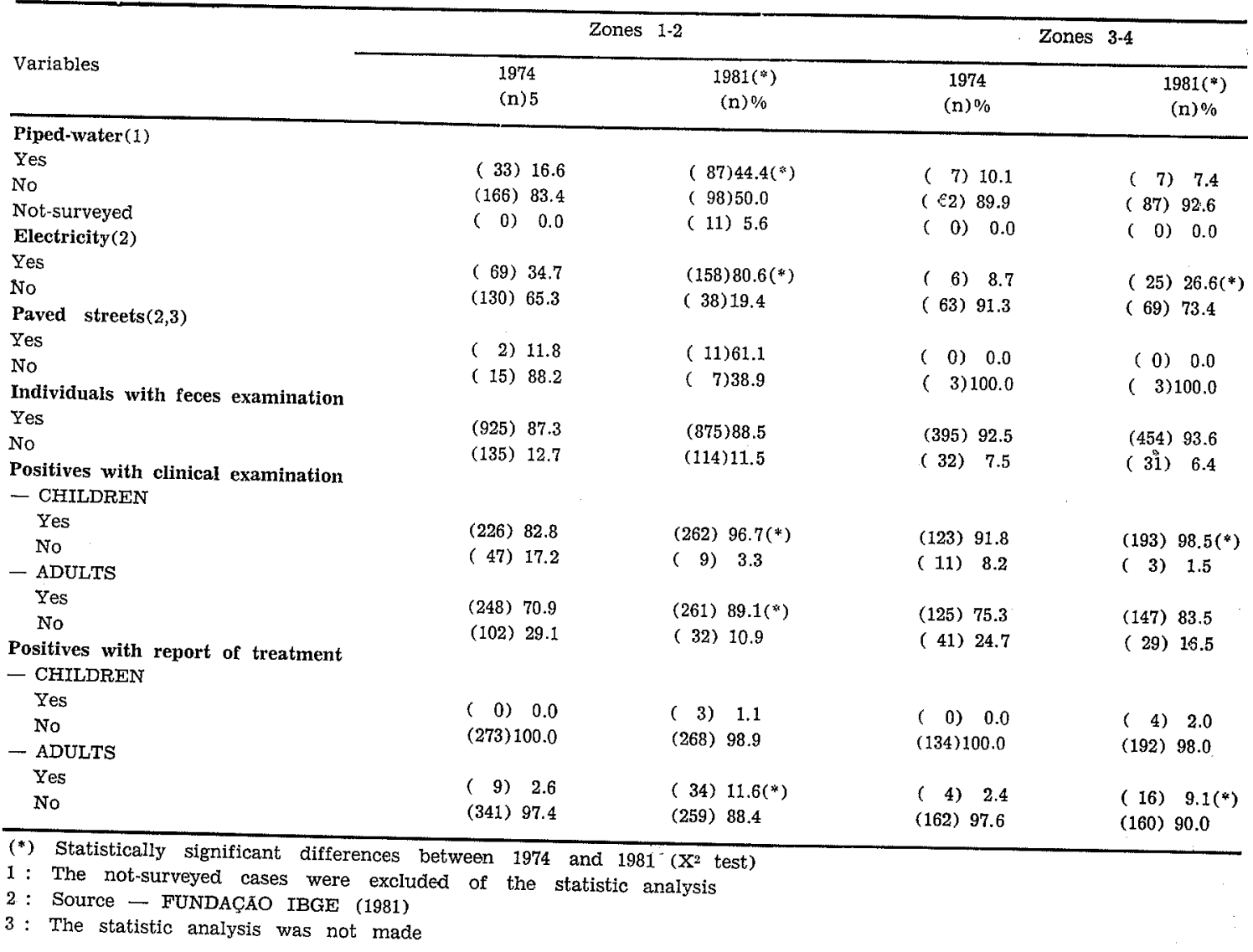

the first feces examination took place. During this period, no schistosomiasis control program was implemented and no socio-economic changes took place in that area. JORDAN et al. 8.9 in St. Lucia developed a project of control of schistosomiasis in 5 places, which consisted of providing all the houses with piped water. After 2-5 years the rate of infection and the $\mathbf{S}$. mansoni egg counts had decreased significantly. In the control areas, the rate of infection and the egg counts increased. BHAJAN et al. ${ }^{2}$ found that the infection by $\mathbf{S}$. mansoni had decreased in school children from different endemic areas in Puerto Rico ten years after the first examination. These Authors used multiple regression analysis to verify that the decrease was strongly related to the improvement of water supply. HIATT et al. ${ }^{7}$ accomplished a program of control of schistosomiasis in Boqueron (Puerto Rico), that consisted of the use of molluscicide, marsh draining, cleaning of the streams and sa- nitary education. After 5 years they concluded that the rate of infection and the mean of $\mathbf{S}$. mansoni eggs had not undergone important alterations.

In the present investigation, the rate of infection did not change during the period analysed, but the counting of eggs in the feces and the rate of splenomegaly decreased significantly. in 1981, when compared to that observed in 1974 (Table I). These changes occurred exclusively in the central zones of Comercinho (zones 1-2) while in the environs (zones 3-4) the egg count and the rate of splenomegaly did not change (Table II).

The egg counts decreased in adults and children from the central zones suggesting that in both groups the contact with natural waters had decreased. The reduction of splenomegaly was significant in the children from zones 1-2 
COSTA, M. F. F. de L. e; ROCHA, R. S.; ZICKER, F. \& KATZ, N. - Evolution of schistosomiasis in an hyperendemic area of the Minas Gerais State: two cross-sectional studies. Rev. Inst. Med. trop. São Paulo 27:279-285, 1985.

(10.6 to $2.6 \%$ ) while in the adults the difference between 1974 and 1981 (from 9.2 to $5.1 \%$ ) was not statistically significant. The adults in endemic areas often show a splenomegaly that started years ago. In this way, the decreasing of the rate of splenomegaly in the children suggests that the changes responsible for the decreasing occurred recently.

Several points should be discussed to try to explain the differences between the data obtained in 1974 and 1981 in the central zones of Comercinho. The proportion of children from zones 1-2 that had been clinically examined was lower in 1974 than in 1981. In spite of this, the number of splenomegaly found in 1974 (24 cases in 226 positive individuals) was three times higher than the one found in 1981 (6 cases in 262). This shows that there was a real decrease in the number of children with splenomegaly, since the number found in 1974 would not be reached in 1981 even if all the positive children in zones 1-2 were clinically examined (in the last year, only 9 children were not examined - Table III). Another aspect to be considered is that in 1974 the patients without $\mathbf{S}$. mansoni eggs in the feces were not clinically examined. Nevertheless the inclusion of the negative patients in the cross-sectional study done in 1981 did not alter the differences in the rates of splenomegaly between the central zones and the surroundings of Comercinho ${ }^{4}$. KLOETZEL ${ }^{11}$ and BINA ${ }^{3}$ found that specific treatment might decrease the incidence of splenomegaly in schis. tosomiasis endemic areas. In the present investigation, the rate of children which had been treated was small $(0 \%$ in 1974 and $1.5 \%$ in 1981) and did not differ between zones $1-2$ and 3-4 (Table III). Regarding the urban infrastructure of Comercinho, an increased number of houses with electricity was found in zones 1-2 as well as in 3-4. 9 Streets, all in the central zones were paved between 1974 and 1981; the pavement of these streets did not lead to the canalization of any stream. In zones 1-2 the proportion of houses with piped water increased from 16.6 to $44.4 \%$, while in zones 3.4 no significant change was found (10.1 and $7.4 \%$, respectively in 1974 and 1981) (Table III).

These data lead to the following conclusions: a) the increased water supply seems to be the most obvious explanation for the chan ges in the S. mansoni pattern in the central zones of Comercinho; b) although the rate of infection was the same, there was a simultaneous decrease in the rate of splenomegaly and in the S. mansoni egg count in children. This is a strong sign that the decrease of the egg count in endemic zones may be a useful indicator of a decrease of the severe forms of schistosomiasis in the age group 0-14 years.

\section{RESUMO}

\section{Evolução da esquistossomose em uma zona hi- perendêmica do Estado de Minas Gerais: dois estudos seccionais}

Dois estudos seccionais da esquistossomose mansoni foram desenvolvidos na cidade de Comercinho, Estado de Minas Gerais (Brasil), com intervalo de sete anos. Em 1974 e em 1981 foram feitos exames de fezes em, respectivamente, 89 e $90 \%$ da população da cidade (cerca de 1.500 habitantes) e exame clínico em, respectivamente, 78 e $92 \%$ dos pacientes que apresentavam ovos de $\mathbf{S}$. mansoni nas fezes. $O$ índice de infecção pelo $\mathbf{S}$. mansoni não se modificou durante o período analisado $(69,9 \%$ em 1974 e $70,4 \%$ em 1981), mas a média geométrica de ovos por grama de fezes $(431 \pm 4 \mathrm{e}$ $334 \pm 4$, respectivamente) e o índice de esplenomegalia (11 e $7 \%$, respectivamente) diminuíram significativamente em 1981, quando comparado ao observado em 1974 . Esta redução ocorreu exclusivamente nas zonas centrais da cidade (zonas 1-2), onde a percentagem de do. micílios com água encanada aumentou de 17 para $44 \%$. Na periferia (zonas $3-4$ ), onde a porcentagem de domicilios com água encanada não mudou significativamente entre $1974(10 \%)$ e 1981 (7\%), a contagem de ovos de S. mansoni e o índice de esplenomegalia também não sofreram modificações.

\section{ACKNOWLEDGMENTS}

Thanks are due to Gercy de Souza Morais, Pedro Coura and José Ribeiro for their technical assistance, and to Prof. Laís de Lima e Costa Araújo for reviewing the manuscript.

\section{REFERENCES}

1. BARBOSA, F. S. \& VOSS, H. - Evolution of the clinical-gradient of Schistosoma mansoni infection in a small town in north-eastern Brazil. Bull. WId. Hlth. Org. 40: $966-969,1969$.

2. BHAJAN, M. M. ; MARTINEZ, V.; RUIZ-TIBEN, E \& JOBIN, W. R. - Socioeconomic changes and reduc- 
COSTA, M. F. F. de L. e; ROCHA, R. S.; ZICKLER, F. \& KATZ, N. - Evolution of schistosomiasis in an hyperendemic area of the Minas Gerais State: two cross-sectional studies. Rev. Inst. Med. trop. São Paulo 27:279-285, 1985.

tion in prevalence of schistosomiasis in Puerto Rico. Bol. Asoc. Méd. P. Rico 70: 106-112, 1978.

3. BINA, J. C. - Influência da terapêutica especifica na evolução da esquistossomose mansoni. Rev. Pat. Trop. 10: 221-267, 1981.

4. COSTA, M. F. F. L.; ROCHA, R. S.; MAGALHÃES, M. H. A. \& KATZ, N. - A clinical-epidemiologic survey of schistosomiasis mansoni in a hyperendemic area in Minas Gerais State (Comercinho, Brazil). I. Difierences in the manifestations of schistosomiasis in the town centre and in the environs. Trans. R. Soc. Trop. Med. Hyg. 79: 539-545, 1985.

5. COSTA, M. F. F. L.; MAGALHÃES, M. H. A.; ROCHA, R. S. \& KATZ, N. - Water contact and socio-economic variables in the epidemiology of schistosomiasis in a Brazilian hyperendemic area: a case-control study. (In preparation).

6. FUNDAÇÃO INSTITUTO BRASILEIRO DE GEOGRA. FIA E ESTATISTICA. Dados sobre os domicílios de Comercinho, Medina, 1981.

7. HIATT, R. A.; CLINE, B. L.; RUIZ-TIBEN, E.; KNIGHT, W. B. \& BERRIOS-DURAN, L. A. - The Boqueron project after 5 years: a prospective community-based study of infection with Schistosoma mansoni in Puerto Rico. Am J. Trop. Med. Hyg. 29: 1228-1240, 1980.
8. JORDAN, P.; WOODSTOCK, L.; UNRAU, G. O. \& COOK, J. A. - Control of Schistosoma mansoni transmission by provison of domestic water supplies. Bull. Wld. Hlth. Org. 52: 9-20, 1975.

9. JORDAN, P.; CHRISTIE, J. D. \& UNRAU, G. O. Schistosomiasis transmission with particular reference to possible ecological and biological methods of control. Acta Trop. 37: 95-135, 1980.

10. KATZ, N.; CHAVES, A. \& PELLEGRINO, J. - A simple device for quantitative stool thick-smear technique in schistosomiasis mansoni. Rev. Inst. Med. trop. São Paulo 14: 397-400, 1972.

11. KLOETZEL, K. - A rationale for the treatment of schistosomiasis mansoni, even when re-infection is expected. Trans. R. Soc. Trop. Med. Hyg. 1: 609-610, 1967.

12. PESSOA, S. B. \& BARROS, P. R. - Notas sobre a epidemiologia da esquistossomose mansônica no Estado de Sergipe. Rev. Med. Gir. São Paulo 13: 17-24, 1953.

13. SNEDECOR, G. W. \& COCHRAN, W. G. - Statistical Methods. 6th edit., Yowa, The Yowa State University Press., 1977.

Recebido para publicação em 17/12/1984. 